\title{
EMPLOYEE PERCEPTIONS OF THE RELATIONSHIP BETWEEN STRATEGY, REWARDS AND \\ Organizational PerformanCE
}

\author{
Richard S. Allen, Ph.D. \\ The University of Tennessee at Chattanooga \\ Chattanooga, TN \\ Marilyn M. Helms, D.B.A., CFPIM, CIRM \\ Dalton State College \\ Dalton, GA
}

\begin{abstract}
This study explores the relationship between organizational strategy, reward practices, and firm performance. Researchers have not extensively investigated this potentially important topic. This paper presents some initial empirical evidence that supports the notion that different types of reward practices more closely complement different generic strategies and are significantly related to higher levels of perceived organizational performance.
\end{abstract}

\section{Employee Perceptions of the Relationships Between Strategy, Rewards and Organizational Performance}

Results of previous research regarding the efficacy of various business strategies has been confusing and contradictory. We suspect that certain reward practices may be associated with stronger organizational performance based on the type of strategy being used by the firm. The use of reward practices which logically complement a specific organizational strategy should serve to motivate employees to help the organization perform at a higher level.

While reward practices may facilitate the successful implementation of organizational strategies, theorists and practitioners, for the most part, have largely ignored this potential relationship (Lawler, Mohrman, and Ledford, 1995; Lawler, 1994; Gomez-Mejia and Balkin, 1992; and Ledford, 1995a). Clearly from both a practitioner and an academic viewpoint, exploratory research on the relationship between reward practices, firm performance and organizational strategies is warranted. It is hoped that this initial exploratory analysis will spur future research into this important research question.

\section{Relevant Literature}

In the next sections, (1) generic organizational strategies; (2) the potential relationship between generic strategies and performance; (3) firm performance measures; and (3) reward practices are discussed. 


\section{Generic Strategies}

While various types of organizational strategies have been identified over the years (Miles and Snow, 1978; Chrisman, Hofer, and Bolton, 1988; Porter, 1980) Porter's generic strategies remain the most commonly supported and identified in key strategic management textbooks (see for example, David, 1999; Miller, 1998; Thompson and Stickland, 1998) and in the literature (Kim and Lim, 1988; Miller and Dess, 1993).

Porter (1980) proposed three generic strategies that can yield competitive advantage, namely cost leadership, product differentiation, and focus. Porter (1980) suggests to ensure long-term profitability, the firm must make a choice between one of the generic strategies rather than end up being "stuck in the middle."

Cost Leadership. Lower costs and cost advantages result from process innovations, learning curve benefits, economies of scale, product designs that reduce manufacturing time and costs, and reengineering activities. A low-cost or cost leadership strategy is effectively implemented when the business designs, produces, and markets a comparable product more efficiently than its competitors. The firm may have access to raw materials or superior proprietary technology which help to lower costs.

Product Differentiation. Product differentiation fulfills a customer need and involves tailoring the product or the service to the customer. This allows organizations to charge a premium price to capture market share. The differentiation strategy is effectively implemented when the business provides unique or superior value to the customer through product quality, features, or after-sale support. Firms following a differentiation strategy can charge a higher price for their products based on the product characteristics, the delivery system, the quality of service, or the distribution channels. The quality may be real or perceived based on fashion, brand name, or image. The differentiation strategy appeals to a sophisticated or knowledgeable consumer who wants a unique, quality product and is willing to pay a higher price.

Focus. Focus, the third strategy, is based on adopting a narrow competitive scope within the industry. Focus strategies grow market share through operating in a niche market or markets that are either not attractive to, or are overlooked by, larger competitors. These niches arise from a number of factors including geography, buyer characteristics, and product specifications or requirements. A successful focus strategy (Porter, 1980) depends upon an industry segment that is large enough to have good growth potential but is not of key importance to other major competitors. Market penetration or market development can be an important focus strategy. Midsized and large firms use focus-based strategies but only in conjunction with differentiation or cost leadership strategies, however focus strategies are most effective when consumers have distinct preferences and when the niche has not been pursued by rival firms (David, 1999). 
According to Porter (1985) focus can be based on (1) differentiation that targets a specific segment of the market with unique needs that are not being met by others in the industry or (2) cost focused where the company has access to specialized production and operations equipment that can save costs in smaller production lots or runs.

As research addressed the relationship between strategy and performance, some studies concluded that only 'pure' strategies (i.e. generic strategies of cost minimization or differentiation) resulted in superior performance, while other research found combination strategies (i.e. low-cost and differentiation) were optimal.

\section{Generic Strategy and Performance}

The strategy literature provides numerous theories, research methodologies, and ideas on the strategy-performance relationship. Strategy research has its roots in industrial organization (IO) theory. Within Bain (1956) and Mason (1939), the IO framework of industry behavior, firm performance or profitability is seen as a function of the industry structure. Industry characteristics rather than firm-based issues are found to determine firm performance (see also Barney, 1986). This structure-conduct-performance model from IO and economics has been used in industries with high concentrations and in similar firms (Seth \& Thomas, 1994). Some studies, however, have not found a link between strategy and performance (McGee \& Thomas, 1986, 1992). Others have found the link between strategy and performance lessened by situational variables including a focus on manufacturing and profitability (Davis \& Schul, 1993; Zahra, 1993).

To investigate the strategy and performance relationship, many researchers began utilizing approaches found to be generalizable across industries, specifically those proposed by Porter (1980, 1985, and 1987).

Pure Generic Strategies. Some researchers found support for Porter's (1980, 1985) original generic strategies (Dess \& Davis, 1984; Hambrick, 1981, 1982; Hawes \& Crittendon, 1984; Nayyar 1993; Parker and Helms 1992; Reitsperger, Daniel, Tallman, Parker \& Chismar, 1993). Dess \& Davis (1984) examined industrial products businesses and suggested performance was achieved through the adoption of a single strategy. Hambrick (1983) investigated capital goods producers and industrial product manufacturers and found support for generic strategies. Ross (1999) also supported two distinct focus strategies including low-cost and differentiation - one aimed at distinct needs in terms of cost in a narrow target market and the other at distinct customization requirements in a narrow target market. Parker and Helms (1992) found superior performance associated with mixed and reactive strategies as well as with single generic strategies.

Combination Generic Strategies. Other researchers found combination strategies to be optimal and associated with superior performance (Buzzell \& Gale, 1987; Buzzell \& Wiersema, 1981; Hall, 1983; Hill, 1988; Murray, 1988; Phillips, Chang, \& Buzzell, 1983; White, 1986; Wright, 1987; Wright, Kroll, Tu, \& 
Helms, 1991). Several studies have suggested that in higher performing businesses, low cost and differentiation strategy may be adopted simultaneously (Gupta 1995; Slocum, McGill, \& Lei 1994). In an attempt to investigate whether low cost and differentiation are mutually exclusive or whether they can be adopted simultaneously. Helms, Dibrell, and Wright (1997) found that business units that simultaneously compete on low cost and differentiation strategies (combination strategies) have higher returns on investment.

Thus, gaps remain in the research. Ironically, some of the research supporting singular generic strategy also produces results that sow seeds of doubt about the relationship between singular generic strategy and superior performance. It appears some businesses succeed only when they combine differentiation and low cost generic strategies (Hill 1988; Murray 1988). For example, White (1986) found that 19 of the 69 business units he examined had the highest ROI and achieved competitive advantage based on combined cost and differentiation strategies. Similar support for a combination strategy was found by Phillips, Chang, and Buzzell (1983). Wright and Parsinia (1988) identified successful firms using combined generic strategies in fragment industries like banking, retailing, distributing, and creative businesses. As a result of these studies and other work, Hill (1988) proposed the generic business-level strategies of differentiation and overall cost leadership are not incompatible but may be combined in some firms to achieve competitive advantage.

In summary, the strategy literature reveals contradictory results on the link between singular generic strategy and performance. As Campbell-Hunt (2000) points out, the dominant paradigm of competitive strategy is now two decades old, but it has yet to prove its adequacy as a descriptive framework or progress its propositions about the performance consequences of different strategic designs.

We believe that the relationship between strategy and performance may be influenced by the type of reward practices used by the organization. This may help to explain some of the confusing and contradictory findings reported in prior stategy-performance studies. Thus, exploratory research on the relationship between strategy, rewards and firm performance is clearly warranted.

\section{Reward Practices}

There is a substantial body of theoretical literature linking organizational strategy, human resource (HR) practices, and performance (Balkin and Gomez-Mejia, 1987; Hambrick and Snow, 1989; Lawler, 1986a; Lawler, 1986b; Ulrich and Lake, 1990; Waldman, 1994, Zingheim and Schuster, 2000). This literature typically suggests that human resource practices should be selected which complement and support an organizational strategy. More specifically, the reward system should be aligned to motivate employee performance that is consistent with the firm's strategy, attract and retain people with the knowledge, skills, and abilities required to realize the firm's strategic goals, and create a supportive culture and structure (Galbraith, 1973; Kilmann, 1989; Nadler and Tushman, 1988). 
Furthermore, the literature argues that alignment of the reward system with organizational strategy helps to determine organizational effectiveness. A review of the literature which links organizational strategy and human resource practices by Becker and Gerhart (1996) suggests the human resource system can be a unique source of competitive advantage, especially when its components have a high degree of internal and external fit. Another review by Gomez-Mejia and Balkin (1992) contends that the old model of compensation (with pay structures based on job analyses, descriptions, specifications, and classifications) is no longer effective in today's business environment. They conclude modern organizations must align their reward system practices with their organizational strategy in order to achieve higher levels of performance at both the individual and organizational level. But this research has remained mainly at the theoretical level. Empirical exploration of these assertions is necessary.

\section{Firm Performance}

While researchers may not always agree on the best strategy, or strategy combination, most if not all, support the long-term benefits of strategic planning for the successful performance of an organization or business unit. However, measuring the performance of a company is challenging. Researchers (e.g., see Buckley, Pass, and Prescott 1988; Littler 1988; Day and Wensley, 1988) disagree about how to both define and operationalize performance.

Most studies on organizational performance use a variety of success measures both financial and non-financial. Researchers employ financial measures such as profit (Saunders and Wong 1985; Hooley and Lynch 1985; Baker, Black, and Hart 1988), turnover (Frazier and Howell 1983), return on investment (Hooley and Lynch 1985), return on capital employed (Baker, Black, and Hart 1988), and inventory turnover (Frazier and Howell 1983). Non-financial measures include innovativeness (Goldsmith and Clutterbuck 1984) and market standing (Saunders and Wong 1985; Hooley and Lynch 1985). When performance is measured at a variety of levels (e.g., national, industry, company, and product), comparison of results is difficult. (Baker and Hart, 1989; Buckley, Pass, and Prescott 1988; and Frazier and Howell, 1983).

Lusch and Laczniak (1989) define business performance as the total economic results of the activities undertaken by an organization. Walker and Ruekert (1987) found primary dimensions of business performance could be grouped into the three categories of effectiveness, efficiency, and adaptability. However there is little agreement as to which measure is best. Thus, any comparison of business performance with only these three dimensions involves substantial trade-offs; good performance on one dimension often means sacrificing performance on another (Donaldson, 1984).

Measures of firm performance generally include such bottom line, financial indicators as sales, profits, cash flow, return on equity, and growth. It is 
important to determine how a firm compares with its industry competitors when assessing firm performance (Dess and Robinson, 1984). Because of the multitude of competitive environments faced by firms in differing industries, knowing only absolute financial numbers such as sales, profits, cash flow, etc., is not very illuminating unless it is put into the context of how well the firm is doing compared to their competition. Furthermore, if only a single industry is studied, the impact of a major economic downturn (or upturn) in that particular industry can overwhelm the effects of any specific variables being studied. Therefore, it is important to use an industry comparison approach when making assessments of firm performance and include organizations from a wide variety of industries in an exploratory study. This approach was used in the study described in this article.

\section{The Research Focus and Hypotheses}

Some limited exploratory survey and empirical work has also been done in this area. In general it has been supportive of the idea the reward system needs to be aligned with the chosen organizational strategy. Allen \& Kilmann (2001) found different types of reward practices exhibit a significant effect on the relationship between a Total Quality Management based strategy and organizational performance. Still other research (see for example Lawler, Mohrman, \& Ledford, 1995) examined a very limited range of four reward practices in a composite index of rewards with regards to employee involvement and TQM. As will be discussed shortly, the present research study explored a much wider range of reward practices and organizational strategies.

Blackburn and Rosen (1993) and Knouse (1995) provide anecdotal support for the proposition of a link between reward practices, strategy, and firm performance in their investigation of quality-focused strategies. They investigated the HR practices of national, state, and local quality award winning organizations and found these organizations, which have been recognized by independent expert examiners as having been successful with their chosen TQM implementation, have typically made changes in their reward systems to make them more supportive of the strategy. Accounts of other successful organizations (Anfuso, 1994; Schonberger, 1994) give further anecdotal support to the notion the reward system must be aligned to support the successful implementation of a quality-focused strategy.

In summary, the literature has remained mostly at the conceptual level in discussing the potential relationship between organizational strategy, the reward system and firm performance. These propositions have remained largely untested and there is a recognized need for exploratory empirical work in this area (Lawler and Jenkins, 1994; Ledford, 1995a; Waldman, 1994). Therefore, the goal of the present study is to begin to empirically explore the potential relationship between the four generic strategies (i.e., cost leadership, product differentiation, focus-cost, and focus-differentiation), a wide range of reward practices and organizational performance. 
The present study considers whether different reward practices used by an organization are related to perceptions of firm performance for organizations utilizing different forms of strategy. Organizational strategy, as noted earlier, can be grouped into four key generic strategies. A priori, we expect higher levels of organizational performance will be associated with different types of reward practices based on the different strategies. Our a priori hypotheses regarding each of Porter's (1985) generic strategies are listed as:

Hypothesis 1: For a product differentiation strategy, specific reward practices (for example, practices that encourage individuals to innovate, develop new products and enhance existing products) will be associated with higher perceived levels or organizational performance.

Hypothesis 2: For a cost leadership strategy, specific reward practices (for example, group based incentives which encourage cost reduction and control, responsibility and authority) will be associated with higher perceived levels of performance.

Hypothesis 3: For a focus-cost leadership strategy, specific reward practices (that emphasize a balance of both customer service as well as cost control) will be associated with higher perceived levels of organizational performance.

Hypothesis 4: For a focus-product differentiation strategy, specific reward practices (emphasizing customer senvice for a unique niche as well as marketing and creativity rewards) will be associated with higher perceived levels of organizational performance.

\section{The Sample}

A convenience sample of 226 employees enrolled in either an evening MBA or weekend Executive MBA program at an urban university were administered the questionnaire.

The survey asked respondents to report their perceptions because actual data is often not available, particulary in private firms. Previous research has used a similar approach for studying reward practices (see Allen and Kilmann, 2001; Lawler, Mohrman, and Ledford, 1995; and Wellins, Ginnodo, Day, Colteryahn, Mussitsch and Price, 1993). A pilot of the survey instrument was conducted with a sample of students, not included in the final results, to ensure respondents understood the questions and had enough organizational knowledge to accurately answer.

Based on the pilot test and post administration interviews it was determined that a respondent needed at least six months of experience working at 
the organization in order to have sufficient organizational knowledge to effectively answer all the questions. Five respondents were deleted because they had less than six months of work experience at a single organization, resulting in a final sample size of 221 and a $97 \%$ response rate. The remaining respondents had an average of four years work experience, and the time employed ranged from six months to 27 years with a standard deviation of 4.37 years.

Position level was also considered as a potential screening device, but pilot and post administration interviews did not uncover any difficulty in completing the survey based on position. Thirty-eight percent held professional or technical positions in their organization, $16 \%$ were in middle management, $16 \%$ were in administrative roles, $11 \%$ were front-line managers, and $6 \%$ were senior managers. All reported adequate organizational knowledge to accurately answer the survey questions.

The organizations included in the sample had a mean number of 1,467 employees with a range from 3 to 57,000. Sixty-two percent were service organizations, $28 \%$ were manufacturing, and $10 \%$ were in the government/nonprofit sector. Seventeen percent of the organizations were unionized. Based on these findings it was concluded that the sample adequately represented the mix of organizations in the region surveyed and closely represented the national population.

\section{Methodology}

\section{Research Instrument}

A questionnaire was developed to explore these hypotheses. Existing scales and items were utilized or adapted where applicable to develop the questionnaire. New items and Likert-type scales were composed when appropriate existing items or scales did not exist. The instrument was pilot tested with a small group of MBA students to verify the understandability of the instrument and to insure that a typical working MBA student had enough organizational knowledge to reasonably answer the questions. Post-pilot interviews were used to refine the instrument.

The questionnaire included a cover page to explain the purpose of the survey and asked respondents to select a single organization as a point of reference to answer the survey questions. Respondents were guaranteed anonymity. If the organization under study had multiple divisions or subsidiaries, respondents were asked to base their answers on the specific division or subsidiary in which they worked. Respondents were given ample time to complete the survey and researchers were on hand to personally administer the questionnaire. Strategy Questions. A review of the strategy literature uncovered no appropriate preexisting scales to measure which type of Porter's generic strategy an organization uses. Therefore it was determined that an appropriate scale would need to be developed for the purpose of this research. A section of twenty-five questions 
regarding the various elements of strategy used by the organization was composed. These items were developed to operationalize each of the four generic strategies based on Porter (1980, 1985) and Parker and Helms (1992). Respondents were asked to estimate how frequently the various strategic practices are used by their organization. Below are samples of the strategy questions and the scale used:

\begin{tabular}{lccccccc}
\hline & \multicolumn{2}{c}{ Almost } & \multicolumn{2}{c}{ About } & \\
& $\begin{array}{c}\text { None } \\
\text { None }\end{array}$ & Some & Half & Most & Almost & All \\
& $(1-20 \%)(21-40 \%)(41-60 \%)(61-80 \%)(81-99 \%)(100 \%)$ \\
\hline Vigorous pursuit of cost reductions & 1 & 2 & 3 & 4 & 5 & 6 & 7 \\
Providing outstanding customer service & 1 & 2 & 3 & 4 & 5 & 6 & 7 \\
Improving operational efficiency & 1 & 2 & 3 & 4 & 5 & 6 & 7 \\
Controlling the quality of products/services & 1 & 2 & 3 & 4 & 5 & 6 & 7 \\
Intense supervision of front-line personnel & 1 & 2 & 3 & 4 & 5 & 6 & 7 \\
Developing brand or company name & & & & & & & \\
$\quad$ identification & 1 & 2 & 3 & 4 & 5 & 6 & 7 \\
Targeting a specific market niche or segment & 1 & 2 & 3 & 4 & 5 & 6 & 7 \\
Providing specialty products/services & 1 & 2 & 3 & 4 & 5 & 6 & 7 \\
\hline
\end{tabular}

Reward Practice Questions. A section asking respondents about the various types of reward practices used in their organization followed the strategic practices section. The reward practice items were developed after a literature review uncovered a list of practices which may impact the success of an organization's strategy. Twenty-four items were adapted to measure a myriad of both monetary and non-monetary reward practices based on existing questionnaires and research by Lawler, Mohrman and Ledford (1995); Wellins, Ginnodo, Day, Colteryahn, Mussitsch and Price (1993); and Allen and Killmann (2001). The respondents were asked to estimate the percentage of employees in the organization who were covered by or eligible for various types of rewards. Example questions are shown below: 


\begin{tabular}{|c|c|c|c|c|c|c|c|}
\hline & $\begin{array}{l}\text { Never } \\
(0 \%)\end{array}$ & $\begin{array}{l}\text { Almost } \\
\text { Never } \\
(1-20 \%)(2\end{array}$ & $\begin{array}{l}\text { Some } \\
\text { times } \\
21-40 \%)(\end{array}$ & $\begin{array}{c}\text { About } \\
\text { Half } \\
(41-60 \%\end{array}$ & $\begin{array}{c}\text { Most } \\
\text { times } \\
(61-80\end{array}$ & $\begin{array}{r}\text { Almost } \\
\text { Always } \\
\%)(81-99\end{array}$ & $\begin{array}{l}\text { Always } \\
\%)(100 \%) \\
\end{array}$ \\
\hline $\begin{array}{l}\text { Employee stock ownership plan - } \\
\text { employees are rewarded with company } \\
\text { stock, thus, giving them an ownership } \\
\text { stake in the organization. }\end{array}$ & 1 & 2 & 3 & 4 & 5 & 6 & 7 \\
\hline $\begin{array}{l}\text { Individual based performance system } \\
\text { performance appraisals, pay increases, } \\
\text { bonuses and promotions are based } \\
\text { primarily on individual achievements } \\
\text { as opposed to work group/team }\end{array}$ & & & & & & & \\
\hline accomplishments. & 1 & 2 & 3 & 4 & 5 & 6 & 7 \\
\hline $\begin{array}{l}\text { Regular expressions of appreciation by } \\
\text { managers/leaders to employees - } \\
\text { such as praise or "pats on the back" to } \\
\text { acknowledge achievement of strategic } \\
\text { goals. }\end{array}$ & 1 & 2 & 3 & 4 & 5 & 6 & 7 \\
\hline $\begin{array}{l}\text { Special Amenities - wherein special } \\
\text { bonuses or perks are used to attract and } \\
\text { retain employees (such as signing } \\
\text { bonuses, extra vacation time, special } \\
\text { work space, company sponsored club } \\
\text { memberships, etc...) }\end{array}$ & 1 & 2 & 3 & 4 & 5 & 6 & 7 \\
\hline
\end{tabular}

Organizational Performance Questions. The sample included a broad range of both publicly and privately held organizations. As such, objective measures of financial and performance were not available. Furthermore, since the sample contained a wide variety of industries purely objective financial data would not be comparable across the sample. Therefore it was necessary to use a more perceptual approach to estimating firm performance. Firm performance was measured using a subjective scale of five items originally developed by Dess and Robinson (1984). The five point, Likert type scale asked respondents to rate how their organization compared to their competitors on a series of key objective performance indicators including total revenue growth, total asset growth, net income growth, market share growth, and overall performance/success. Respondents were asked to compare their organization's level of performance to competitors for each of the five items.

\section{Strategy Scales: Factor Analysis}

The strategy items were subjected to a factor analysis to test whether the items naturally grouped into Porter's $(1980,1985)$ generic strategies. Using SPSS principal component analysis with a Varimax rotation and Kaiser normalization, a four-factor solution emerged that explained $51.2 \%$ of the variance with an eigenvalue of 1.38 . 
Further analysis found these factors conceptually correspond with Porter's $(1980,1985)$ framework of four generic organizational strategies. Items which loaded at .35 or higher were included in the four factors. Four of the original 25 items did not load strongly onto a single factor and were excluded from further analysis, leaving 21 strategy items. The items and factor loadings for each factor are summarized in Table 1.

Table 1

Factor Analysis - Factor Loadings for Different Strategies

\begin{tabular}{|c|c|c|c|c|}
\hline Strategy & $\begin{array}{c}\text { Product } \\
\text { Differentiation }\end{array}$ & $\begin{array}{c}\text { Focus- } \\
\text { Cost } \\
\text { Leadership } \\
\end{array}$ & $\begin{array}{c}\text { Cost } \\
\text { Leadership } \\
\end{array}$ & $\begin{array}{c}\text { Focus- } \\
\text { Product } \\
\text { Differentiation }\end{array}$ \\
\hline $\begin{array}{l}\text { Innovation in marketing technology } \\
\text { and methods }\end{array}$ & .800 & & & \\
\hline Developing brand identification & .738 & & & \\
\hline Utilizing advertising & .709 & & & \\
\hline Refining existing products/services & .708 & & & \\
\hline $\begin{array}{l}\text { Developing a broad range of new } \\
\text { products/services }\end{array}$ & .659 & & & \\
\hline Forecasting new market growth & .658 & & & \\
\hline Forccasting existing market growth & .626 & & & \\
\hline Extensive training of marketing personne: & .594 & & & \\
\hline $\begin{array}{l}\text { Building a positive reputation within the } \\
\text { industry for technological leadership }\end{array}$ & .518 & & & \\
\hline Building high market share & .458 & & & \\
\hline $\begin{array}{l}\text { Controlling the quality of } \\
\text { products/services }\end{array}$ & & .806 & & \\
\hline Providing outstanding customer service & & .749 & & \\
\hline Improving operational efficiency & & .642 & & \\
\hline Extensive training of front-line personnel & & .526 & & \\
\hline Intense supervision of front-line personnel & & .372 & & \\
\hline Vigorous pursuit of cost reductions & & & .872 & \\
\hline Tight control of overhead costs & & & .833 & \\
\hline Targeting a specific market & & & & .626 \\
\hline Providing specialty products/services & & & & .623 \\
\hline Dropping unprofitable customers & & & & .571 \\
\hline $\begin{array}{l}\text { Producing products/services for high } \\
\text { price market segments }\end{array}$ & & & & .538 \\
\hline
\end{tabular}

Cronbach Alphas were computed to check for the reliability of the scales. The product differentiation factor of ten items has an Alpha of 0.89 ; the focus/ 
cost leadership factor of five items had an Alpha of 0.77 , the cost leadership scale consisted of two items with an Alpha of 0.86, and the focus/product differentiation factor with four items had an alpha of 0.57 . While the alpha for factor 4 was not as strong as the other three factors, it is still within the expected range for a broad construct established by Van de Ven and Ferry (1980) and was deemed acceptable. Likewise, the average inter-factor correlations were low and within the acceptable range established by Van de Ven and Ferry (1980). The focus strategies concentrate on smaller, unique, or niche markets and are combination strategies (with differentiation or cost leadership). Thus, they experience more conceptual over-lap in strategic positioning than do the pure forms of cost leadership or product differentiation. Therefore, their Alphas would be expected, a priori, to be lower than the purer forms of strategy.

Product Differentiation Factor. Because a product differentiation strategy emphasizes the uniqueness of a product or service and attempts to make the product or service unique in the mind of the customer, we would expect marketing related actives to predominate. All factor loadings are indeed marketing related and emphasize developing or refining products and services and planning for market growth. By fostering innovation as well as building a reputation of technological leadership a firm should be assured of a stream of new innovations to attract the interests of new customers as well as to meet existing customer's demands for uniqueness.

Focus-Cost Leadership Factor. For this factor we would expect an emphasis on reducing costs while at the same time meeting the needs of an undeveloped niche. The items which loaded highly on this factor support this strategy. By providing outstanding customer service a previously neglected market segment is catered to. The variables of improving operational efficiency and controlling quality emphasize the overarching cost objectives. Quality is important to insuring low costs because producing a product or delivering a service right the first time eliminates rework and scrap costs. Extensive training and supervision of front-line personnel will also serve to meet customer needs by streamlining processes to provide for cost efficiency.

Cost Leadership Factor. Only two items loaded on the cost leadership factor. It would have been preferable if more items represented this strategy, but the two item results make conceptual sense. A deep discount retailer which uses a pure, cost minimization strategy, for example, stresses ongoing cost reductions and tight control of overhead costs to exclusion of almost any other organizational issues. This is contrasted with a Focus-Cost Leadership retailer that also competes on the basis of providing outstanding customer service and quality in addition to low costs. It was also determined that adding additional items to this scale reduced the Chronbach alpha. As such, it was concluded that these two items adequately captured the essence of a cost leadership strategy.

Focus-Product Differentiation Factor. The Focus-Product Differentiation factor again emphasizes a unique product or service but to smaller, possibly undefined or overlooked specialty niches. Variables important to this strat- 
egy would be the ones that loaded on this factor. First, targeting a specific market and providing them with specialty products and service is by definition, the focus - product differentiation strategy. Dropping unprofitable customers ensures an even tighter focus, while providing products and services for high price market segments further focuses the strategy on customers with unique needs.

Organizational Performance Scale. The Cronbach Alpha for the organizational performance scale was computed to be 0.95 . This compares favorably to previous research using this scale to measure organizational performance of 0.93 (Allen \& Kilmann, 2001).

\section{Analysis and Results}

Descriptive Statistics and Correlations are presented in Table 2. The correlation matrix indicates that there are some strong correlations between many of the variables, but these correlations make conceptual sense and were expected. Real organizations rarely follow one of the generic strategies to the letter. Most organizations strategies are a hybrid of the generic strategies. For example, there is a .49 correlation between the Product Differentiation and Focus-Product Differentiation strategies. These two strategies, by definition have a great deal of conceptual overlap as previously discussed in this article.

Likewise, there is a strong correlation between use of the four strategies and firm performance. This is also understandable because organizations, which implement a discernable strategy are more likely to be successful than those that are stuck in the middle.

Our original list of twenty-four reward practices had a lot of correlations between reward practice items. This also made conceptual sense. An organization employing one particular type of reward practice is likely to use another similar reward practice. For example, an organization which places an emphasis on teamwork is likely to use such related reward practices as work group incentives, employee stock ownership, profit sharing and gain sharing.

In order to help control for possible multi-collinearity in our data and explore the relationships between the variables a stepwise variation of multiple regression was utilized. Organizations that scored above the mean on each of the four strategy scales were included in a regression equation along with the reward practices as independent variables and firm performance as the dependent variable. The regression analysis found that eight of the original 24 reward practices were associated with significantly higher levels of performance for the different types of strategies. Sixteen insignificant reward practices were discarded by the step-wise regression as not adding significant explanatory power regarding the variance in firm performance. The regression results for the four hypotheses are summarized in Table 3. 
Table 2

Descriptive Statistics and Correlation Matrix

\begin{tabular}{|c|c|c|c|c|c|c|c|c|c|c|c|c|c|c|c|}
\hline & Mean & SD & $\mathbf{N}$ & 1 & 2 & 3 & 4 & 5 & 6 & 7 & 8 & 9 & 10 & 11 & 12 \\
\hline 1. Product Differentiation & 45.91 & 12.30 & 206 & & & & & & & & & & & & \\
\hline 2. Cost Leadership & 9.78 & 3.10 & 218 & $.32 * *$ & & & & & & & & & & & \\
\hline 3. Focus-Cost Leadership & 25.95 & 5.25 & 219 & $.52 * *$ & $.34 * *$ & & & & & & & & & & \\
\hline 4. Focus-Product Differentiation & 16.96 & 4.64 & 212 & $.49 * *$ & $.29 * *$ & $.30^{* *}$ & & & & & & & & & \\
\hline $\begin{array}{l}\text { 5. Individual Based Performance } \\
\text { System }\end{array}$ & 4.86 & 2.06 & 218 & $.26^{* *}$ & .03 & $.23 * *$ & .10 & & & & & & & & \\
\hline 6. Employee Stock Ownership & 2.43 & 2.11 & 217 & $.33 * *$ & $.16^{*}$ & .10 & $.20^{* *}$ & $.26^{* * *}$ & & & & & & & \\
\hline $\begin{array}{l}\text { 7. Regular Expressions of } \\
\text { Appreciation by } \\
\text { Managers/Leaders to Employees }\end{array}$ & 4.48 & 1.78 & 218 & $.39^{* *}$ & .06 & $.41^{* *}$ & $.21^{* *}$ & $.26 * *$ & .12 & & & & & & \\
\hline 8. Increased Job Autonomy & 3.66 & 1.68 & 215 & $.26^{* *}$ & .10 & $.29 * *$ & $.14^{*}$ & $.19^{* *}$ & $.17^{*}$ & $.44^{* *}$ & & & & & \\
\hline 9. Special Amenities & 2.69 & 1.86 & 214 & $.25^{* *}$ & -.01 & $.16^{*}$ & $.19 * *$ & $.21^{* *}$ & $.26^{* *}$ & $.27^{* *}$ & $.34^{* *}$ & & & & \\
\hline 10. Narrow Pay Bands & 4.42 & 1.69 & 215 & .07 & .11 & $.15^{*}$ & .07 & -.06 & -.30 & .11 & .12 & .08 & & & \\
\hline 11. Position Based Pay System & 5.32 & 1.70 & 217 & $.19^{* *}$ & $.15^{*}$ & .12 & .07 & $.28 * *$ & .12 & .04 & -.04 & -.01 & .09 & & \\
\hline $\begin{array}{l}\text { 12. Developmental Based } \\
\text { Performance Appraisals }\end{array}$ & 3.63 & 1.94 & 216 & $.39^{* *}$ & .11 & $.39 * *$ & $.21^{* *}$ & $.26 * *$ & $.22^{* *}$ & $.42^{* *}$ & $.40^{* *}$ & $.34^{* *}$ & $.14^{*}$ & $.17^{*}$ & \\
\hline 13. Firm Performance & 17.63 & 5.48 & 177 & $.55^{* *}$ & $.34 * *$ & $.48^{* *}$ & $.30^{* *}$ & $.35 * *$ & $.39 * *$ & $.42^{* *}$ & $.35 * *$ & $.35 * *$ & .14 & .05 & $.37 * *$ \\
\hline
\end{tabular}


Table 3

Stepwise Regression Results - Standardized Beta Coefficients

\begin{tabular}{lcccc}
\hline Strategy & $\begin{array}{c}\text { Product } \\
\text { Differentiation }\end{array}$ & $\begin{array}{c}\text { Cost } \\
\text { Leadership }\end{array}$ & $\begin{array}{c}\text { Focus- } \\
\text { Cost } \\
\text { Leadership }\end{array}$ & $\begin{array}{c}\text { Focus* } \\
\text { Product } \\
\text { Differentiation }\end{array}$ \\
\hline $\begin{array}{l}\text { Individual Based Performance System } \\
\text { Employee Stock Ownership }\end{array}$ & $0.216^{*}$ & & & $0.280^{* *}$ \\
$\begin{array}{l}\text { Regular Expressions of Appreciation by } \\
\quad \text { Managers/Leaders to Employees }\end{array}$ & $0.254^{*}$ & $0.300^{* *}$ & $0.204^{*}$ & \\
$\begin{array}{l}\text { Increased Job Autonomy } \\
\text { Special Amenities }\end{array}$ & $0.232^{*}$ & $0.244^{*}$ & $0.281^{* *}$ & \\
$\begin{array}{l}\text { Narrow Pay Bands } \\
\text { Position Based Pay System }\end{array}$ & & $0.239^{*}$ & & $0.236^{*}$ \\
Developmental Based Performance & & & $0.195^{*}$ & $0.184^{*}$ \\
$\quad$ Appraisals & & & $0.208^{*}$ & \\
$\mathrm{R}^{2}$ & & & $-0.200^{*}$ & \\
F-Statistic & 0.241 & 0.296 & & 0.321 \\
\hline
\end{tabular}

${ }^{*} p<0.05 ;{ }^{* *} p<0.01 ;{ }^{* * *} p<.001$

\section{Discussion and Conclusions}

Hypothesis 1, regarding the product differentiation strategy, resulted in three reward practices being associated with higher levels of organizational performance. These three reward practices were: (1) an individual based performance system in which pay increases, bonuses and promotions are based on the accomplishment of individual goals, (2) employee stock ownership, and (3) regular expressions of appreciation by managers/leaders to employees such as praise or "pats on the back" to acknowledge the accomplishment of strategic goals. The use of both monetary (performance rewards such as raises and bonuses) and non-monetary rewards (promotions, stock and recognition) logically bolster both the extrinsic and intrinsic motivation of employees to innovate and achieve a differentiated product or service. Because the product differentiation strategy stresses tailoring the product or services to the customer who is willing to pay a higher price for the service, we would expect individual and/or company incentives or rewards based on sales growth to be particularly effective. Likewise, a differentiation strategy hinges on the ability of the organization to innovate to provide unique products or services. A reward system that recognizes and rewards individuals for developing new ideas and innovations would logically support this sort of strategy. We suspect having both individual based performance systems as well as an employee stock ownership plan would encourage employees to achieve both short term and long term goals. The reward of regular expressions of appreciation by managers or leaders to employees 
would also be important as a mechanism to recognize employees who provide excellent or exceptional customer service.

Hypothesis 2, regarding the cost leadership strategy, shared two reward practices with the product differentiation strategy. First, consistent with behavior modification and reinforcement theory (Skinner, 1953; Luthans \& Kreitner, 1985) regular expressions of appreciation by managers and leaders to employees are important to encourage behavior of employees that helps move the organizations towards reaching strategic goals - regardless of the goal or strategy chosen. Here rewarding employees for ideas to minimize or eliminate costs would be more important. Also employee stock ownership programs would motivate employees towards helping the organization achieve their long-term strategy. In this instance, the long-term nature of stock ownership would ensure an ongoing cost reduction emphasis. Finally, the unique reward practice of increased job autonomy in which employees are rewarded with increased decision making and control is important to allow employees freedom to investigate, locate, and correct product or service defects or procedures at their source. This reward is well supported in the quality literature of Deming (1982), Juran (1992), and Crosby (1979). These well-known quality theorists support increased job autonomy, allowing employees the freedom to make changes in their job to improve quality and efficiency and thereby reduce costs. For example, assembly line workers in many auto plants have the authority to stop the line in order to correct a quality problem.

The significant reward practices for hypothesis 3 (regarding a focus-cost leadership strategy) again indicated the importance of regular expressions of appreciation by managers and leaders to employees, regardless of the strategy chosen. Consistent with Organizational Behavior literature (Pfeffer, 1998; Luthans \& Kreitner, 1985; Kerr, 1975), recognition serves to motivate employees to reach higher levels of performance. Table 3 identifies four other reward practices important for a focus-cost leadership strategy. Because this strategy emphasizes serving a unique niche, special amenities may be necessary to attract and retain the type of employees who have the requisite skills to cater to the unique customers targeted by this strategy. Likewise, in keeping with a cost leadership philosophy, the provision of perks like special parking spaces, club memberships and special workspace may actually cost less than the constant recruiting and replacement of workers with the specialized skills necessary to perform in this market niche.

The final three reward practices supporting the focus-cost leadership strategy deal exclusively with pay issues: (1) narrow pay bands, (2) position-based pay systems, and (3) employee stock ownership. As previously discussed, stock ownership encourages appropriate long-term oriented behavior. The use of position based pay systems (which pay people primarily based on the level they hold in the organization) can have an adverse impact on total payroll expense and thus, deter a cost leadership strategy. Employees in this system are paid based on the position they hold, rather than for their performance. Accordingly, the use of this pay system was negatively correlated with firm performance. 
The use of narrow pay bands (few differences in pay for a given position) should result in cost containment as payroll costs are held in check as contrasted with performance based or skill based pay plans which reward people with higher salaries based on their performance or skills acquired. Narrow pay bands should also help achieve a perception of relative pay equity among employees (Adams, 1965) thus, keeping absenteeism, turnover, and low morale costs down.

For the final hypothesis, concerning the generic strategy of focus-product differentiation, we find an individual-based performance system to be supportive. This is consistent with the generic product differentiation strategy discussed earlier. This pay system would encourage product or service differentiation, but within a niche market. In agreement with the other focus strategy, focus-cost leadership, special amenities are necessary to attract and retain employees with the specialized skills required to effectively target the niche market's customers.

Development-based performance appraisals, being more future oriented than strictly past performance based appraisals, should enable employees to gain the skills necessary in the future to allow them to better differentiate their products and services to niche customers. As shown in Table 3, the increased job autonomy reward was important for this strategy as well. In this case, more autonomy should empower employees with the appropriate decision making latitude to provide the level of customer service required for their unique market niche and to be permitted to make the necessary decisions to allow their organization's service to be sufficiently differentiated from the competition.

\section{Limitations of this Study}

Little research has investigated the relationship between strategy, rewards, and performance. This research used a convenience sample to begin to explore this important research question and develop hypothesis. As such, future research may be strengthened by using a sample comprised of more senior managers and upper-level administrators, thus, limiting variability in the sample and controlling for experience, organizational level, industry type, and other diversities.

The wide variability in the types of organizations participating this sample helped to bolster the generalizability of the findings, but precluded using objective measures of firm performance. While this sample adequately mirrored the regional business community, future research designs may be improved by studying a single industry and utilizing objective, measures of performance. This would necessitate using only publicly held firms in a single industry as the sample. The downside to this approach would be less generalizability of findings and the greater potential for an industry specific event (i.e., upturn or downturn) to mask the relationships.

A longitudinal research design should also be considered in future research. The presently used cross-sectional approach precluded cause-and-effect conclusions because data was collected at one time from a single source. Future 
research should collect data on a longitudinal basis to aid in drawing causal inferences.

Considering these limitations, the findings and conclusions of the present study should be viewed as exploratory and tentative. Stronger research designs and methods should be used in the future to verify the findings of the present study.

\section{Implications for Managers}

Even though this study was exploratory in nature, the results are interesting for executives and top managers and match much of the popular literature and discussions about aligning rewards to strategy for optimal organizational performance. The popular press urges us that "what gets measured gets done" and "what gets rewarded gets accomplished" so the notion of matching rewards to strategy are intuitively appealing to practitioners as well as academicians.

Our findings have important, practical implications for senior managers and others responsible for the implementation of strategies and rewards in organizations. Top managers must work closely with lower-level managers as well as human resources professionals to craft reward systems that are consistent with motivational concepts and at the same time support their chosen organizational strategy. The relationship between strategy and rewards needs to be clearly communicated to the employees so that they understand the organization's strategy as well as the linkages between their rewards and strategy.

Human resource professionals should be closely involved in the strategy formation and implementation process. Top managers should consider involving cross-functional teams in developing both strategic plans and supportive reward practices. More specifically, managers should implement policies and programs that link performance to the accomplishment of strategic objective at all organizational levels supported by reward practices which foster rather than hinder the espoused organizational strategy.

Based on the current research, one would expect that strategies must be clearly articulated and then effectively deployed throughout the organization. At the same time, the reward system must be continually adapted to provide corresponding reinforcement and advancement of the chosen strategy.

\section{Areas for Further Research}

More than anything else, this study underscores the importance of tailoring reward systems for the strategy espoused by the organization. This set of findings reinforces Lawler's (1991) comments about the important relationship between reward systems and all change efforts including the overall organizational strategy. Clearly, this exploratory study should encourage others to proceed with further empirical research on the inter-relationship between strategy, rewards and performance.

The preliminary findings of this research need to be verified and more deeply studied to uncover the psychological underpinnings that are responsible 
for the results reported in this study. Future research should be designed to test whether or not these different reward practices actually moderate the performance of organizations. For example, is there an interaction effect between the use of increased job autonomy and a cost leadership strategy to produce higher levels of organizational performance?

As with any exploratory research, more interesting and important research questions have been uncovered. For example, why do individual based performance systems appear to be supportive of both the Differentiation strategies (Product and Focus), but not the two Cost Leadership forms of strategy? Why were ESOPs supportive of all but the Focus-Product Differentiation strategy? Why were some highly regarded forms of rewards like profit sharing, gainsharing, team-based incentives, skill-based pay, group celebrations, and other non-monetary forms of recognition not significantly linked with any type of strategy? These are all areas for future research.

Moreover, we encourage researchers to improve on the limitations to the present study. To begin with, a more geographically diverse sample of individuals and organizations should be included in subsequent studies. The use of a convenience sample served our initial theory-building aims but reaching a broader geographic range of organizations is needed. Furthermore, rather than relying on the recall of employees, as we did, other studies could access the actual formal strategic and financial documents of organizations so they can be content analyzed independently of other data and, thereby, neither rely on recall nor the possibilities of common variance from all data being provided by the same respondents. Perhaps a series of case-study efforts could be made to work with several organizations willing to supply not only their formal documents, but also allowing researchers to interview employees concerning their strategic and reward system practices as well.

This exploratory study is a start, but it has only touched the tip of the iceberg on this important research question. Our understanding of strategies and rewards can be significantly improved by further study of their relationships.

\section{References}

Adams, J.S. (1965). Inequity in social exchange. In L. Berkowitz (Ed.) Advances in experimental social psychology, 2, (pp. 267-299). New York: Academic Press.

Allen, R.S. \& Kilmann, R.H. (2001). The role of the reward system for a Total Quality Management based strategy. Journal of Organizational Change Management, 14(2), 110-131.

Anfuso, D. (1994). At L. L. Bean, quality starts with people: 1994 Optimas award winners. Personnel Journal, 73(1), 60.

Bain, J.S. (1956). Barriers to new competition. Cambridge, MA: Harvard University Press. 
Baker, M.J., Black, C.D., \& Hart S. (1988). The competitiveness of British industry: What really makes the difference? European Journal of Marketing, 22(2), 70-85.

Baker, M.J., \& Hart S. (1989). Marketing and competitive success. Hemel Hempstead: Philip Allan.

Balkin, D.B. \& Gómez-Mejia, L.R. (1987). Toward a contingency theory of compensation strategy. Strategic Management Journal, 8, 169-182.

Barney, J.B. (1986). Types of competition and the theory of strategy: Toward an integrated framework. Academy of Management Review, 110, 791-800.

Becker, B. \& Gerhart, B. (1996). The impact of Human Resource Management on organizational performance: Progress and prospects. Academy of Management Journal, 39(4), 779-801.

Blackburn, R. and Rosen, B. (1993). Total Quality Management and Human Resources Management: Lessons learned from Baldrige award winning companies. Academy of Management Executive, 7(3), 49-66.

Buckley, P., Pass, C.L. \& Prescott, K. (1988). Measures of international competitiveness: A critical survey. Journal of Marketing Management, 4, 175-200.

Buzzell, B.T. \& Gale, B.T. (1987). The PIMS principles: Linking strategy to performance. New York: The Free Press.

Buzzell, R.D. \& Wiersema, F.D. (1981). Successful share building strategies. Harvard Business Review, 59(1), 135-144.

Campbell-Hunt, C. (2000). What have we learned about generic competitive strategy? A meta-analysis. Strategic Management Journal, 21(2), 127-154.

Chrisman, J., Hofer, C., \& Bolton, W. (1988). Toward a system for classifying business strategies. Academy of Management Review, 13, 413-28.

Crosby, P.B. (1979). Quality is free. New York: New American Library.

David, F. (1999). Strategic management concepts and cases. New Jersey: Prentice-Hall.

Davis, P.S. \& Schul, P.L. (1993). Addressing the contingent effects of business unit strategic orientation on relationships between organizational context and business unit performance. Journal of Business Research, 27(3), 183-200.

Day, G.S., \& Wensley, R. (1988). Assessing advantage: A framework for diagnosing competitive superiority. Journal of Marketing, 52, 1-20.

Deming, E.W. (1982). Out of the crisis. Cambridge, MA: Massachusetts Institute of Technology Center of Advanced Engineering Study. 
Dess, G.G. \& Davis, P.S. (1984). Porter's generic strategies as determinants of strategic group membership and performance. Academy of Management Journal, 26(3), 467488.

Dess, G.G. and Robinson, R.B., Jr. (1984). Measuring organizational performance in the absence of objective measures. Strategic Management Journal, 5, 265-273.

Donaldson, G. (1984). Managing corporate wealth. New York: Praeger.

Frazier, G.L., and Howell, R.D. (1983). Business definition and performance. Journal of Marketing, 47, 59-67.

Galbraith, J.K. (1973). Controls or competition - what's at issue? Review of Economics and Statistics, 55(4), 524-538.

Goldsmith, W., \& Clutterbuck, D. (1984). The winning streak: Britain's top companies reveal their formulas for success. London: Weidenfield and Nicolson.

Gomez-Mejia, L.R. \& Balkin, D.B. (1992). Compensation, organizational strategy, and firm performance. Cincinnati, $\mathrm{OH}$ : Southwestern Publishing Company.

Gupta, A. (1995). A stakeholder analysis approach for inter-organizational systems. Industrial Management \& Data Systems, 95(6), 3-7.

Hall, W. K. (1983). Survival in a hostile environment. In R. G. Hammermesh (Ed.) Strategic management. (pp. 15I-169). New York: John Wiley \& Sons.

Hambrick, D.C. (1981). Strategic awareness within top management teams. Strategic Management Journal, 2(2), 263-279.

Hambrick, D.C. (1982). Environmental scamning and organizational strategy. Strategic Management Journal, 3(1), 159-174.

Hambrick, D.C. (1983). Some tests of the effectiveness and functional attributes of Miles and Snow's strategic types. Academy of Management Journal, 26(1), 5-26.

Hambrick D.C. and Snow, C.C. (1989). Strategic reward systems, In C.C. Snow (Ed.) Strategy organizational design and human resource management. (pp. 929-964) Greenwich, CT: JAI Press.

Hawes, J.M. \& Crittendon, W.F. (1984). A taxonomy of competitive retailing strategies. Strategic Management Journal, 5(2), 275-287.

Helms, M.M., Dibrell, C. \& Wright, P. (1997). Competitive strategies and business performance: Evidence from the adhesives and sealants industry. Management Decision, 35, 678-92. 
Hill, C.W.L. (1988). Differentiation versus low cost or differentiation and low cost: A contingency framework. Academy of Management Review, 13(3), 401-412.

Hooley, G.I., \& Lynch, J.E. (1985). Marketing lesson's from the UK's high-flying companies. Journal of Marketing Management, 1, 65-74.

Juran, J.M. (1992), Juran on quality by design. New York: The Free Press.

Kerr, S. (1975). On the folly of rewarding A, while hoping for B. Academy of Management Journal, 18, 769-783.

Kilmann, R.H. (1989). Managing beyond the quick fix. San Francisco, CA: Jossey-Bass.

Kim, L. and Lim, Y. (1988). Environment, generic strategies, and performance in a rapidly developing country: A taxonomic approach. Academy of Management Journal, 31, 802-827.

Knouse, S.B. (1995), The reward and recognition process in Total Quality Management. Milwaukee, WI: ASQC Quality Press.

Lawler, E.E., III. (1991). The new plant approach: A second generation approach. Organization Dynamics, 20(1), 4-15.

Lawler, E.E., III. (1986a). High involvement management. San Francisco, CA: JosseyBass.

Lawler, E.E., III. (1986b). Reward systems and strategy. In J. R. Gardner, R. Rochlin \& H. W. Sweeney (Eds.) Strategic planning handbook. New York: Wiley.

Lawler, E.E. III. (1994). Total Quality Management and employee involvement: Are they compatible? Academy of Management Executive, 8(1), 68-76.

Lawler, E.E., III \& Jenkins, G.D. (1994). Strategic reward systems. In M. D. Dunnette \& L. M. Hough (Eds.) Handbook of industrial and organizational psychology. (2nd ed., pp. 3-94.) Palo Alto, CA: Consulting Psychologist Press Inc.

Lawler, E.E., III, Mohrman, S.A. \& Ledford, G.E., Jr. (1995). Creating high performance organizations: Practices and results of employee involvement and Total Quality Management in Fortune 1000 companies. San Francisco, CA: Jossey-Bass.

Ledford, G.E., Jr. (1995a). Pay as an Organizational Development issue. Academy of Management ODC Newsletter, Summer, 1-6.

Ledford, G.E., Jr. (1995b). Designing nimble reward systems. Compensation and Benefits Review, July-August, 27, 46-54.

Littler, D. (1988). Perspectives on competitiveness. Marketing Education Group Proceedings of the 21 st Annual Conference, Huddersfield Polytechnic, 3, 57-72. 
Lusch, R.F., \& Laczniak, G.R. (1989). Macro-environmental forces, marketing strategy and business performance: A futures approach. Journal of the Academy of Marketing Science, $17,283-95$.

Luthans, F. \& Kreitner, R. (1985). Organizational behavior modification and beyond. Glenview, IL: Scott Foresman.

Mason, E.S. (1939). Price and production policies of large-scale enterprises. American Economic Review, 29(1), 61-74.

McGee, J. \& Thomas, H. (1986). Strategic groups: Theory, research and taxonomy. Strategic Management Journal, 7(1), 141-160.

McGee, J. \& Thomas, H. (1992). Strategic groups and intra-industry competition. International Review of Strategic Management, 3, 77-98.

Miles, R.E. \& Snow, C.C. (1978). Organizational strategy, structure, and process. New York: West.

Miller, A. (1998). Strategic Management. (3rd ed.). New York: Irwin McGraw-Hill.

Miller, A. \& Dess, G. (1993). Assessing Porter's (1980) model in terms of its generalizability, accuracy, and simplicity. Journal of Management Studies, 30, 553585 .

Murray, A. I. (1988). A contingency view of Porter's generic strategies, Academy of Management Review, 13(3), 390-400.

Nadler, D. \& Tushman, M. (1988). Strategic organization design. Glenview, IL: Scott, Foresman.

Nayyar, P.R. (1993). On the measurement of competitive strategy: Evidence from a large multiproduct US firm. Academy of Management Journal, 36(6), 1652-1669.

Parker, B., \& Helms, M.M. (1992). Generic strategies and firm performance in a declining industry. Management International Review, 32(1), 23-29.

Pfeffer, J. (1998). Six dangerous myths about pay. Harvard Business Review, 76, 108 119.

Phillips, L.W., Chang, D.R. \& Buzzell, R.D. (1983). Product quality, cost position, and business performance: A test of some key hypotheses. Journal of Marketing, $47(2)$, $26-43$.

Porter, M.E. (1980), Competitive strategy. New York: Free Press.

Porter, M.E. (1985). Competitive advantage: Creating and sustaining superior performance. New York: Free Press. 
Porter, M.E. (1987). From competitive advantage to corporate strategy. Harvard Business Review, 65(3), 43-59.

Reitsperger, W.D., Daniel, S.J., Tallman, S.B., Parker, B. \& Chismar, W.G. (1993). Product quality and cost leadership: Compatible strategies? Management International Review, 33, 7-21.

Ross, D.N. (1999). Culture as a context for multinational business: A framework for assessing the strategy-culture 'fit'. Multinational Business Review, 7(1), 13-19.

Saunders, J., \& Wong, V. (1985). In search of excellence in the UK. Journal of Marketing Management, 1, 119-37.

Schonberger, R.J. (1994). Human resource management lessons from a decade of total quality management and reengineering. California Management Review, 36(4), 109-124.

Seth, A. \& Thomas, H. (1994). Theories of the firm: Implications for strategy research. Journal of Management Studies, 31(2), 165-191.

Skinner, B.F. (1953). Science and human behavior. New York: Free Press.

Slocum, J.W. Jr., McGill, M., \& Lei, D. (1994). The new learning strategy: Anytime, anything, anywhere. Organizational Dynamics, Autumn, 23(2). 33-48.

Thompson, A. \& Strickland, A. (1998). Crafting and implementing strategy. New York: Irwin McGraw-Hill.

Ulrich, D. \& Lake, D. (1990). Organizational capability. New York: John Wiley and Sons.

Van de Ven, A.H., \& Ferry, D.L. (1980). Measuring and assessing organizations, New York: John Wiley and Sons.

Waldman, D.A. (1994). Designing performance management systems for Total Quality implementation. Journal of Organizational Change Management, 7(2), 31-44.

Walker, O.C., Jr., \& Ruekert, R.W. (1987). Marketing's role in the implementation of business strategies: A critical review and conceptual framework. Journal of Marketing, 51, 15-33.

Wellins, R.S., Ginnodo, W.L., Day, C.R. Jr., Colteryahn, K.L., Mussitsch, K. \& Price, D. (1993). TQM: Forging ahead or falling behind? A study of quality practices. Pittsburgh, PA: Development Dimensions International.

White, R.E. (1986). Generic business strategies, organizational context, and performance: An empirical investigation. Strategic Management Journal, 7(2), 217-231. 
Wright, P. (1987). A refinement of Porter's strategies. Strategic Management Journal, $8(1), 93-101$.

Wright, P. \& Parsinia, A. (1988). Porter's synthesis of generic business strategies: A critique. Industrial Management, May-June, $20-23$.

Wright, P., Kroll, M., Tu, H. \& Helms, M. (1991). Generic strategies and business performance: An empirical study of the screw machine products industry. British Journal of Management, 2(I), 57-65.

Zahra, S.A. (1993). Environment, corporate entrepreneurship, and financial performance: A taxonomic approach. Journal of Business Venturing, 8(3), 319-340.

Zingheim, P. K. \& Schuster, J.R. (2000). Total rewards: Pushing the pedal to the metal. The Journal of Business Strategy, July/August, 21(4), 15-17.

Richard Allen is the UC Foundation Assistant Professor of Management at the University of Tennessee at Chattanooga. His research interests include organizational development and the strategic use of rewards. Prior to entering academia, he spent over 15 years in a variety of corporate management, training and consulting roles.

Marilyn Helms is the Sesquicentennial Endowed Chair and Professor of Management at Dalton State College in Dalton, GA. Her research interests include manufacturing strategy, quality, and international management. She has international experience teaching in Tokyo, Japan; and directing study abroad programs teaching at Manchester Business School and at Kings College-Kensington (London); Cairns and Sydney, Australia; and Dublin and Galway, Ireland. She was awarded the Fulbright Teaching and Research Award and taught at the University of Coimbra, Portugal from April to June 2000. 